\title{
KUALITAS PELAYANAN RADIO JAYA PEMUDA INDONESIA ( JPI ) FM SOLO DI SURAKARTA \\ (Suatu Analisis Tanggapan Monitor Aktif)
}

\author{
A. Fidhdiarr Ariestanto T.N.K \\ Program Studi Manajemen \\ Fakultas Ekonomi \\ Universitas Boyolali \\ email: kafidiar@yahoo.com
}

\begin{abstract}
ABSTRAKSI
Tujuan penelitian ini untuk Mengetahui komponen-komponen kualitas pelayanan ( tangibles, realibility, responsiveness, assurance dan emphaty ) yang paling dominan yang ada di radio JPI FM Solo dan Untuk mengetahui kepuasan konsumen mengenai kualitas pelayanan jasayang ada di radio JPI FM Solo. Hipotesis komponen reliability dan emphaty yang paling dominan dalam pelayanan yang ada di radio JPI FM Solo dan Tidak ada perbedaan yang signifikan antara rata-rata kualitas pelayanan yang diharapkan dengan rata-rata kualitas pelayanan yang dirasakan / diterima konsumen radio JPI FM Solo.

Penelitian ini merupakan penelitian korelasional yang dimaksudkan untuk melakukan pengamatan yang cermat akan fenomena sosial tertentu, yang ditujukan untuk pemecahan masalah yang ada pada masa sekarang. Metode yang digunakan dalam penelitian ini adalah metode survai sehingga memerlukan beberapa konsumen yang dijadikan sampel untuk diselidiki perilakunya.

Hasil penelitian bahwa berdasarkan penilaian skala yang ada, sebenarnya semua hasil dari nilai yang dirasakan bernilai tinggi. Meskipun demikian berdasarkan analisis data yang telah dilakukan, kualitas pelayanan Radio JPI FM pada umumnya masih kurang baik.Terlihat bahwa dari 5 dimensi kualitas pelayanan yang ada, tidak satupun bernilai positif.Kualitas pelayanan yang bernilai negatif ini menunjukkan bahwa pelayanan yang dirasakan konsumen lebih rendah daripada yang mereka harapkan.
\end{abstract}

Kata Kunci: Kepuasan Konsumen, Perilaku Konsumen, Kualitas Pelayanan

\section{ABSTRACT}

The purpose of this study was to determine the components of service quality (tangibles, reliability, responsiveness, assurance and empathy) that are most dominant in JPI FM Solo radio and to determine customer satisfaction regarding the quality of service services on JPI FM Solo radio. Hypothesis of the components of reliability and empathy is the most dominant in the service that is on JPI FM Solo radio and there is no significant difference between the average expected service quality and the average service quality felt / received by JPI FM Solo radio consumers.

This research is a correlational research which is intended to make careful observations of certain social phenomena, which are aimed at solving problems that exist in the present. The method used in this research is a survey method so that it requires several consumers to be sampled to investigate their behavior.

The result of the research is that based on the existing scale assessment, in fact all the results of the perceived value are of high value. However, based on the data analysis that has been done, the service quality of JPI FM Radio is generally still not good. It can be seen that of the 5 dimensions of service quality, none of them has a positive value. they expected.

Keywords: Customer Satisfaction, Consumer Behavior, Service Quality 


\section{PENDAHULUAN}

Radio siaran swasta sebagai salah satu perusahaan jasa yang bergerak dalam bidang usaha informasi dan hiburan yang berorientasi terhadap para konsumen memerlukan suatu pengelolaan yang profesional dengan tujuan tidak saja agar memperoleh keuntungan melalui kepuasan konsumen namun juga memperoleh nama baik. Untuk mendapatkan keunggulan kompetitif maka setiap perusahaan dituntut untuk mampu memuaskan konsumennya. Komitmen manajemen untuk meningkatkan kualitas pelayanan untuk memuaskan pelanggan secara terus menerus dilakukan oleh perusahaan. Kualitas barang atau jasa semata-mata ditentukan oleh konsumen, sehingga kualitas yang baiklah yang hanya dapat memuaskan konsumennya. Konsumen yang puas dapat mendorong adanya pembelian ulang dan publisitas yang pada akhirnya dapat membuat konsumen menjadi setia. Untuk dapat menghasilkan kepuasan para konsumennya, terlebih dahulu harus memahami siapa yang ada di pasar konsumen (=siapa pendengar saya), apa yang dibeli konsumen (= apa jenis siaran yang ingin didengarkan), kapan konsumen membeli (=kapan saya akan didengarkan), siapa yang terlibat dalam pembelian (=tipe macam apa pendengar saya), mengapa konsumen membeli (= bagaimana komposisi kelompok), dan bagaimana konsumen membeli (= pendengar tersebut individu atau kelompok)( Dharmmesta dan Handoko, 2000: 18 ).

Kepuasan yang diterima para konsumennya secara tidak langsung akan menciptakan kesetiaan, dan merupakan media promosi yang sangat efektif.. Seiring perkembangan media komunikasi saat ini, radio menempatkan diri sebagai media komunikasi yang lebih memasyarakat dibandingkan dengan media komunikasi yang lain. Siaran radio mempunyai sikap auditif, dimana penyampaian pesan dilakukan melalui bahasa lisan serta berkesan akrab dengan pendengarnya. Sebagai media komunikasi massa, radio mempunyai fungsi antara lain: media penerangan dan pemberitaan, media pendidikan, media siaran dan kebudayaan serta media hiburan. Namun selain fungsifungsi tersebut, radio juga mempunyai fungsi yang lebih dominan, yaitu fungsi komersial sebagai media promosi. Siaran radio dapat digunakan sebagai media pemasaran dengan jalan melalui pemasangan iklan.

Zeithaml, Parasuraman dan Berry (ZPB, 1988 : 23) mengemukakan lima dimensi yang menentukan kualitas pelayanan ditinjau dari sudut pandang pelanggan, yaitu, pertama, tangibles yaitu penampilan dan kemampuan sarana dan prasarana fisik yang dapat diandalkan untuk memberikan pelayanan sesuai dengan yang telah dijanjikan.

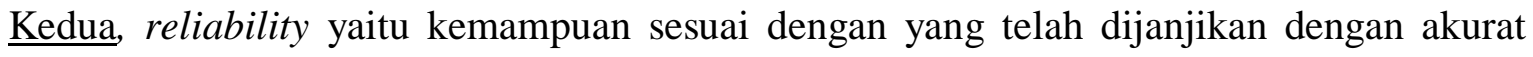
dan terpercaya. Ketiga, responsiveness yaitu keinginan untuk membantu para pelanggan dan memberikan pelayanan dengan sebaik mungkin. Keempat, assurance yaitu pengetahuan dan kesopansantunan para pegawai perusahaan serta kemampuan mereka untuk menumbuhkan rasa percaya para pelanggan kepada perusahaan. Kelima, emphaty yaitu perhatian yang tulus yang diberikan kepada para pelanggan.

Berdasarkan uraian diatas tersebut, maka penelitian tentang kualitas pelayanan Radio JPI FM di Surakarta perlu diteliti lebih mendalam yang mencakup kelima dimensi kualitas pelayanan Parasuraman, Zeithaml, dan Berry dengan membandingkan antara pelayanan yang diharapkan dan pelayanan yang dirasakan oleh konsumen. 


\section{LANDASAN TEORI DAN KAJIAN PUSTAKA.}

\section{A. KONSEP PEMASARAN}

Pemasaran adalah suatu proses sosial dengan mana seseorang atau kelompok memperoleh apa yang mereka butuhkan dan inginkan melalui penciptaan, penawaran dan pertukaran produk dan nilai." (Kotler, 2000:8).

Pemasaran adalah suatu sistem total dari kegiatan bisnis yang dirancang untuk merencanakan, menentukan harga, mempromosikan dan mendistribusikan barang-barang yang dapat memuaskan keinginan dan jasa baik kepada para konsumen saat ini maupun konsumen potensial." ( Stanton, 1996: 7 ).

Konsep pemasaran adalah kunci untuk mencapai tujuan organisasi yang terdiri dari pemenuhan kebutuhan dan keinginan pasar sasaran dan menyerahkan produk yang memuaskan secara efektif dan efisien dibanding para pesaing." (Kotler, 2000: 19).

Konsep pemasaran adalah sebuah falsafah bisnis yang menyatakan bahwa pemuasan kebutuhan konsumen merupakan syarat ekonomi dan sosial bagi kelangsungan hidup perusahaan. Tujuan dari penggunaan konsep pemasaran adalah bertujuan memberikan kepuasan terhadap keinginan dan kebutuhan pembeli / konsumen." (Dharmmesta, 2000 : $10)$.

\section{B. KEPUASAN KONSUMEN}

Kotler (2000:38) mengungkapkan empat cara yang dapat dilakukan dalam rangka pengukuran kepuasan konsumen. Cara-cara tersebut adalah:

a. Sistem Keluhan dan saran

b. Survey kepuasan konsumen

c. Pembeli bayangan

d. Analisis pelanggan yang beralih.

C. PEMASARAN JASA DAN RUANG LINGKUPNYA.

Berbagai faktor bisa dikemukakan sebagai pemicu perkembangan sektor jasa yang sedemikan pesat diantaranya (Fandy Tjiptono,2000:4):

1. Adanya peningkatan pengaruh sektor jasa dalam perekonomian.

2. Waktu santai yang semakin banyak.

3. Adanya peningkatan kompleksitas kehidupan.

4. Perubahan teknologi berlangsung semakin cepat.

D. PERILAKU KONSUMEN DALAM PEMILIHAN JASA.

Suatu konsepsi mengenai bagaimana perilaku ini terjadi dan dibentuk merupakan model perilaku konsumen yang dimiliki oleh setiap orang. Perilaku konsumen dalam memilih suatu jasa sangat dipengaruhi oleh pengalaman dan kepercayaan konsumen atas kualitas jasa tersebut (Zeithaml dan Bitner, 2000 :59)

Dalam merencanakan pemasaran jasa, ada beberapa hal yang harus dipenuhi, yaitu (Engal, Blackwell dan Miniard, 1994:132):

1. Pengambilan keputusan merupakan suatu bagian dari loyalitas terhadap suatu merek tertentu.

2. Akan ada perbedaan dari satu konsumen ke konsumen yang lain. Mungkin ada banyak pangsa dengan motivasi dan perilaku proses keputusan

E. KUALITAS PELAYANAN 
Fandy Tjiptono (2000:51) mengungkapkan bahwa tidak ada definisi mengenai kualitas yang dapat diterima semua orang. Namun demikian ada elemen yang sama dalam berbagai definisi yang ada, diantaranya adalah:

1. Kualitas berkaitan dengan memenuhi atau melebihi harapan konsumen.

2. Kualitas berlaku untuk jasa, manusia, proses, dan lingkungan.

3. Kualitas adalah kondisi yang selalu berubah.

\section{F. DEFINISI OPERASIONAL}

1. Kualitas pelayanan adalah selisih antara persepsi terhadap kualitas pelayanan yangditerima monitor Radio JPI FM dengan harapan monitor radio JPI FM terhadap kinerja Radio JPI FM.

2. Variabel kualitas pelayanan.

a. Bukti langsung (tangibles)

b. Keandalan (reliability)

c. Daya tanggap (responsiveness)

d.Jaminan (assurance)

e. Empati (emphaty)

3. Analisis kualitatif monitor
a. Jenis kelamin
b. Usia
c. Pekerjaan
d. Tingkat berkunjung
e. Tujuan berkunjung
f. Alasan berkunjung

\section{G. KERANGKA PEMIKIRAN.}

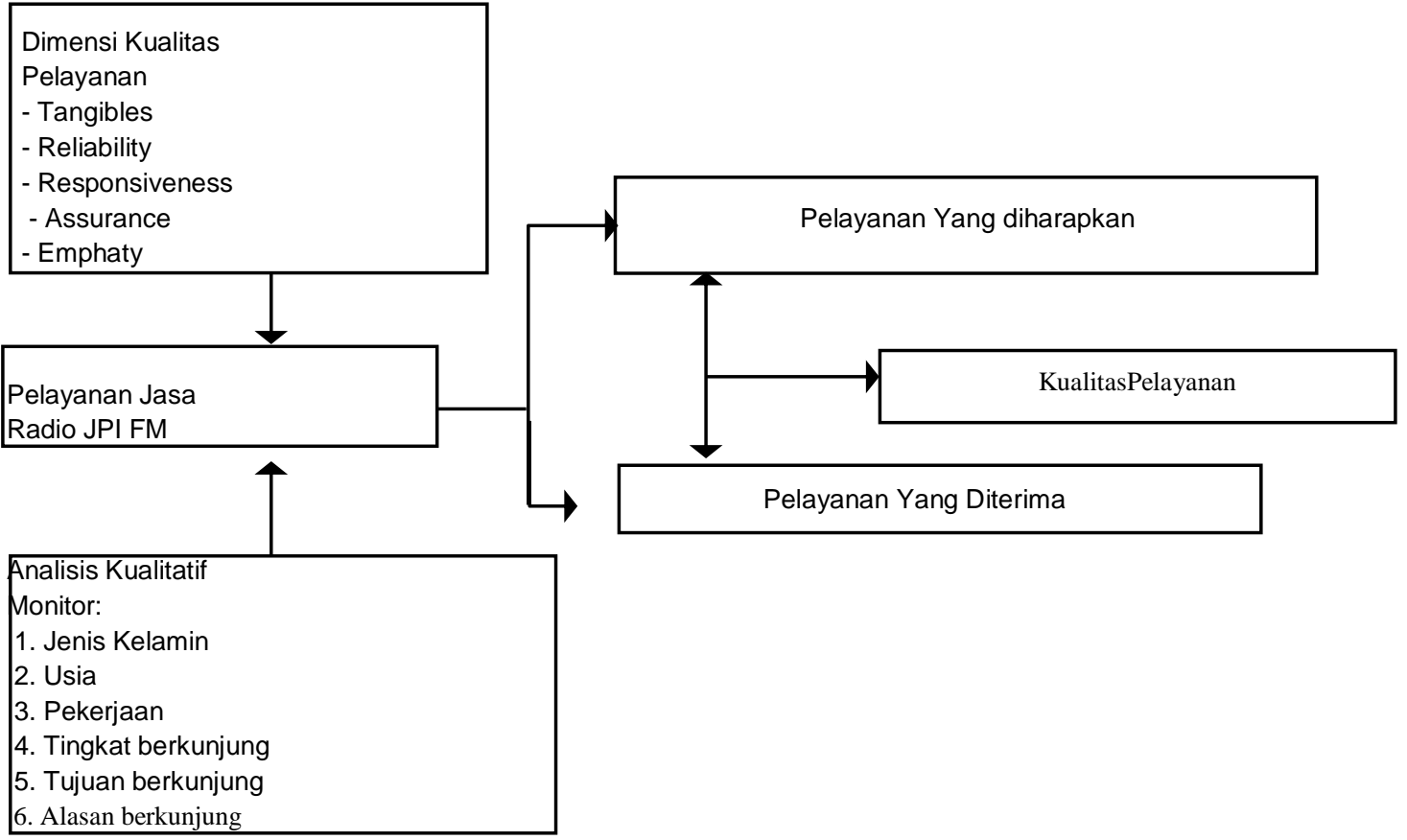

\section{H. HIPOTESIS}


1. Komponen reliability dan emphaty yang paling dominan dalam pelayanan yang ada di radio JPI FM Solo.

2. Tidak ada perbedaan yang signifikan antara rata-rata kualitas pelayanan yang diharapkan dengan rata-rata kualitas pelayanan yang dirasakan / diterima konsumen radio JPI FM Solo.

\section{METODE PENELITIAN.}

\section{A. RUANG LINGKUP PENELITIAN.}

Penelitian ini merupakan penelitian korelasional yang dimaksudkan untuk melakukan pengamatan yang cermat akan fenomena sosial tertentu, yang ditujukan untuk pemecahan masalah yang ada pada masa sekarang. Metode yang digunakan dalam penelitian ini adalah metode survai sehingga memerlukan beberapa konsumen yang dijadikan sampel untuk diselidiki perilakunya

B. JENIS DAN SUMBER DATA

1. Data Primer

a. Data tentang karakteristik responden.

b. Data harapan konsumen terhadap kualitas pelayanan yang dibagi dalam beberapa dimensi dan atribut.

c. Data pelayanan yang dirasakan sesuai dengan dimensi dan atribut harapan diatas.

2. Data Sekunder.

Adalah data yang diperoleh dari berbagai sumber yang dianggap relevan dengan masalah penelitian.

\section{POPULASI DAN SAMPEL}

Populasi penelitian adalah monitor aktif Radio JPI FM Solo dan sampel penelitian diambil dari beberapa responden. Metode pengambilan sampel yang digunakan adalah metode simple random sampling dimana sampel diambil secara acak dengan jumlah sampel sebanyak 100 orang

\section{TEKNIK PENGUMPULAN DATA DAN UJI INSTRUMEN}

1. Teknik Pengumpulan Data
a. Kuesioner
b. Interview/ wawancara
c. Observasi
d. Studi Pustaka

Pengukuran data dilakukan dengan format jawaban tipe Likert yang menggunakan skala tujuh tingkat (Likert) yang terdiri dari sangat tidak setuju, tidak setuju, kurang setuju, netral, agak setuju, setuju, sangat setuju. Ketujuh penilaian tersebut digunakan dalam penilaian harapan dan kinerja dengan bobot sebagai berikut:

- Jawaban sangat setuju diberi bobot 7

- Jawaban setuju diberi bobot 6

- Jawaban agak setuju diberi bobot 5 
- Jawaban netral diberi bobot 4

- Jawaban kurang setuju diberi bobot 3

- Jawaban tidak setuju diberi bobot 2

- Jawaban sangat tidak setuju diberi bobot 1

2. Uji Instrumen

a. Uji Validitas

Uji validitas dalam penelitian ini menggunakan teknik korelasi product moment person. Uji validitas ini dilakukan dengan mengkorelasikan antara skor yang diperoleh dari masing-masing itempertanyaan dengan skor total. Tinggi rendahnya validitas suatu angket dihitung denganteknik korelasi product moment (Singarimbun, 1995: 137):

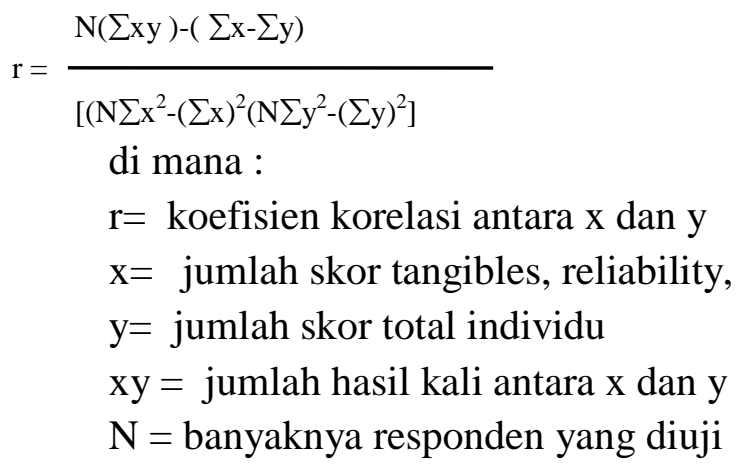

Pengujian validitas ini dilakukan melalui bantuan komputer Program SPSS for Windows Release 10.0.

b. Reliabilitas.

Dalam penelitian ini, pengujian reliabilitas menggunakan pendekatan rumus koefisien $\alpha$ (alpha) (Azwar,2000: 184) sebagai berikut:

$$
\left.\alpha=\frac{\left(1-{ }^{k}\right.}{k-1}\right) \frac{\sum S_{j}^{2}}{S^{2} x}
$$

dimana

$\mathrm{k}$ = banyaknya belahan

$\mathrm{S}^{2}{ }_{\mathrm{j}}=$ varians skor belahan

$\mathrm{S}^{2} \mathrm{X}=$ varians skor total

$\alpha=$ koefisien reliabilitas alpha

Perhitungan koefisien reliabilitas dilakukan melalui bantuan komputer Program SPSS for Windows Release 10.0. Semakin tinggi nilai koefisien alpha atau semakin mendekati 1,00 semakin tinggi pula tingkat reliabilitasnya

\section{E. TEKNIK ANALISIS DATA}

\section{Analisis Kualitatif-Deskriptif}

a. Analisis berdasarkan pengelompokan jenis kelamin responden

b. Analisis berdasarkan pengelompokan usia responden

c. Analisis berdasarkan pengelompokan pekerjaan responden 
d. Analisis berdasarakan pengelompokan seringnya berkunjung

e. Analisis berdasarkan tujuan responden berkunjung

f. Analisis berdasarkan alasan responden berkunjung.

2. Analisis Kuantitatif-Inferensial

a. Uji hipotesis Pertama

1) Analisis Atribut

Analisis dilakukan untuk menilai masing-masing item yang menggambarkan kualitas pelayanan yang ada berdasarkan hasil nilai skor masing -masing atribut yang ada di dalam instrumen servqual Instrumen ini dikembangkan oleh Zeithaml, Berry dan Parasuraman (1988).

2) Analisis Keluhan Pelanggan.

Tingkat keluhan pelanggan dapat tercermin dari seberapa bagus pelayanan yang telah diterima konsumen. Analisis ini dilakukan berdasarkan nilai rata-rata minimal dari dimensi kualitas pelayanan yang diterima konsumen di Radio JPI FM. Dikatakan baik bila rata-rata yang dihasilkan minimal sesuai dengan rata-rata keseluruhan dari masing- masing dimensi, atau dikatakan kurang baik bila rata-rata yang dihasilkan berada kurang dari rata-rata keseluruhan dari masing-masing dimensi.

3) Analisis Perbedaan Kualitas Pelayanan.

Dalam analisis ini akan diperoleh perbedaan antara rata-rata kualitas pelayanan yang diharapkan monitor dengan rata-rata kualitas pelayanan yang diterima monitor di radio JPI FM Solo. Perbedaan kualitas pelayanan yang diketahuii dengan cara mengamati selisih antara harapan konsumen dengan pelayanan yang telah diterima konsumen. Selisih negatif menunjukkan bahwa harapan konsumen belum terpenuhi sedangkan selisih positif menunjukkan bahwa harapan konsumen telah terpenuhi.

b. Uji Hipotesis kedua

Uji Z

H0 (hipotesis nol): Tidak ada perbedaan yang signifikan antara rata-rata kualitas pelayanan yang diharapkan konsumen dengan rata-rata kualitas pelayananyang dirasakan konsumen Radio JPI FM Solo.

Ha (Hipotesis alternatif) : Ada perbedaan yang signifikan antara rata-rata kualitas pelayanan yang diharapkan konsumen dengan rata-rata kualitas pelayanan yang dirasakan konsumen Radio JPI FM Solo.

\section{ANALISIS DATA DAN PEMBAHASAN}

Penelitian dilakukan di Radio JPI FM Solo. Penelitian ini bertujuan untuk menganalisis kualitas pelayanan Radio JPI FM Solo, dengan cara membandingkan antara kualitas pelayanan yang diharapkan konsumen dengan kualitas pelayanan yang dirasakan (diterima) konsumen .Untuk mengarah ke tujuan tersebut, maka dilakukan pengumpulan informasi dengan metode survey yaitu menyebarkan kuesioner pada konsumen Radio JPI FM Solo. Subyek penelitian ini adalah Konsumen/monitor aktif Radio JPI FM Solo. Sedangkan obyek penelitiannya adalah persepsi dan harapan atas kualitas pelayanan Radio JPI FM Solo. Kuesioner yang dibagikan kepada responden 
tersebut ditujukan khusus untuk mengetahu i/ menganalisis kemungkinan timbulnya perbedaaan pada kualitas pelayanan yang diharapkan konsumen dengan yang dirasakannya. Dengan cara ini pihak manajemen radio dapat melihat komponen mana saja yang harus ditingkatkan kualitas pelayanannya sehingga sesuai dengan harapan konsumen.

Kuesioner yang dibagikan kepada konsumen terdiri dari tiga bagian, yaitu :

Bagian I: identitas responden, berguna untuk memperoleh informasi/identitas responden.

Bagian II: ukuran harapan (expectation) digunakan untuk mengukur apa yang diharapkan konsumen tentang pelayanan Radio JPI FM Solo.

Bagian III: ukuran kinerja (performance), digunakan untuk mengetahui persepsi ataukualitas pelayananyang dirasakan konsumen Radio JPI FM Solo.

\section{A. ANALISIS VALIDITAS DAN RELIABILITAS.}

1. Uji Validitas

Dalam pengujian validitas terhadap instrumen riset, dilakukan dalam 2 bagian. Bagian pertama dalam kuesioner yang disebarkan ditujukan untuk mengukur harapan konsumen tentang pelayanan Radio JPI FM, yang terdiri dari 20 butir pernyataan. Sedangkan bagian kedua berisi tentang persepsi konsumen mengenai pelayanan Radio JPI FM atau pelayanan yang diterima (dirasakan) oleh konsumen. Kuesioner yang dibuat terdiri dari 20 butir pernyataan yang dikelompokkan ke dalam 5 dimensi kualitas pelayanan, sebagai berikut :

\begin{tabular}{|l|l|}
\hline \multicolumn{1}{|c|}{ Dimensi } & \multicolumn{1}{c|}{$\begin{array}{c}\text { Pernyataan yang berkaitan } \\
\text { dengan Dimensi }\end{array}$} \\
\hline Tangible & Pernyataan nomer 1- 4 \\
Reliability & Pernyataan nomer 5 - 8 \\
Responsiveness & Pernyataan nomer $9-12$ \\
Assurance & Pernyataan nomer 13 - 16 \\
Emphaty & Pernyataan nomer 17 - 20 \\
\hline
\end{tabular}

a. Uji Validitas Kuesioner Bagian Pertama.

Pada tes validitas kuesioner tersebut, tidak terdapat satu itempun (dari 20 item) yang gugur. Hal ini terlihat dari nilai koefisien validitas masingmasing item lebih dari 0,3 ( biasa digunakan dalam pengembangan dan penyusunan skala-skala psikologi - semakin tinggi korelasi mendekati angka 1,00 maka semakin baik pula konsistensinya). Dengan demikian semua item dapat diikutkan dalam perhitungan dan analisis data selanjutnya.

b. Uji Validitas Kuesioner Bagian Kedua

I. Dimensi Tangibles

1. Bangunan dan penataan berbagai fasilitas RJPI FM menarik

2. Karyawan RJPI FM berpakaian rapi dan mencerminkan citra professional

3. Furniture dan perlatan elektronik di studio modern

4. Area parkir memadai

II. Dimensi Reliability

5. Karyawan bersikap simpatik dalam membantu kesulitan konsumen

6. RJPI FM menyediakan berbagai jenis pelayanan yang dibutuhkan

7. Pelayanan yang diberikan sesuai dengan yang dijanjikan

8. Karyawan melayani kebutuhan konsumen dengan benar

III Dimensi Responsiveness

9. RJPI FM memberikan pelayanan yang tepat waktu

10. Karyawan selalu siap dan bersedia membantu konsumen 


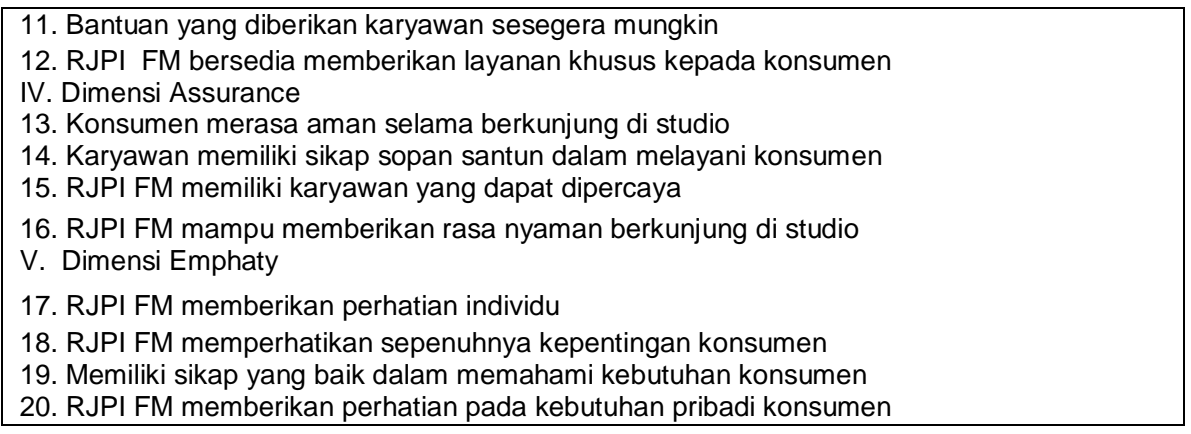

2. Uji Reliabilitas.

Hasil uji reliabilitas kuesioner untuk konsumen Radio JPI FM untuk bagian satu menghasilkan angka standardized item alpha $=0,9389$.Angka ini menunjukkan derajat reliabilitas yang tinggi karena mendekati angka 1,00. Sedangkan uji reliabilitas untuk bagian dua, dengan hasil standardized item alpha sebesar 0,9334. Angka ini juga menunjukkan derajat reliabilitas yang tinggi, karena mendekati angka 1,00.

B. ANALISIS KUALITATIF - DESKRIPTIF

Analisis kualitatif-deskrptif ini dapat dibagi menjadi beberapa bagian, yaitu :

1. Analisis berdasarkan pengelompokan jenis kelamin responden

2. Analisis berdasarkan pengelompokan usia responden

3. Analisis berdasarkan pengelompokan pekerjaan responden

4. Analisis berdasarkan pengelompokan seringnya berkunjung di Radio JPI FM

5. Analisis berdasarkan tujuan responden berkunjung di Radio JPI FM

6. Analisis berdasarkan alasan responden berkunjung di Radio JPI FM

C. ANALISIS KUANTITATIF - INFERENSIAL

1. Uji Hipotesis Pertama

a. Analisis Atribut pada Dimensi tangible.

Pada dimensi ini, perusahaan diharapkan untuk meningkatkan kualitas pelayanan pada keempat item yang dinilai masih kurang bagus, dimana masih bernilai negatif $(-0.1 ;-0.56 ;-0.13 ;-0,62)$. Dengan kata lain Radio JPI FM diharapkan mampu untuk menata berbagai fasilitasnya dengan lebih menarik dan lebih meningkatkan citra profesional yang dicerminkan lewat busana karyawan. Disamping itu furniture dan peralatan elektronik di studio harus lebih modern, serta area parkir harus lebih memadai.

b. Analisis atribut pada Dimensi Reliability.

Pada dimensi ini perushaan diharapkan untuk lebih meningkatkan usahausahanya untuk meningkatkan inerjanya pada item-item yang masih bernilai negatif pada umumnya dan khususnya pada item yang memiliki skor perbedaan yang paling rendah, yaitu item kelima. Dengan kata lain perusahaan diharapkan lebih meningkatkan kinerjanya untuk lebih mendorong karyawan bersikap lebih simpatik dalam membantu kesulitan konsumen (item kelima), perusahaan harus memiliki karyawan yang dapat melayani kebutuhan konsumen dengan benar ( item ke delapan) menambah berbagai jenis pelayanan yang dibutuhkan konsumen (item 
keenam), dan yang terakhir ,lebih memberikan pelayanan yang sesuai dengan yang dijanjikan (item ketujuh).

c. Analisis Atribut pada Dimensi responsiveness

Sedangkan analisis berdasarkan perbedaan rata-rata item, terdapat satu item yang bernilai positif, yaitu bahwa Radio JPI FM bersedia memberikan layanan khusus (item 12). Sedangkan tiga item lainnya masih bernilai negatif. dalam dimensi ini perusahaan mampu meningkatkan kualitas pelayanannnya denagn cara lebih memberikan pelayanan yang tepat waktu, kesiapan dan kesediaan karyawan dalam membantu konsumen, dan bantuan yang diberikan karyawan diharapkan lebih cepat (sesegera mungkin).

d. Analisis Atribut pada Dimensi Assurance.

Analisis pada dimensi assurance ini bila didasarkan pada rata-rata item, terdapat satu item yang memiliki pelayanan yang cukup bagus, yaitu pada item yang memiliki pelayanan yang cukup bagus, yaitu pada item ke-14, dimana ditunjukkan bahwa item ini mempunyai nilai positif $(0,29)$. Ini berarti pelayanan yang dirasakan (diterima) lebih tinggi dari yang diharapkan konsumen. Dalam hal ini konsumen menilai karyawan Radio JPI FM telah memiliki sikap sopan santun dalam melayani mereka.

e. Analisis Atribut pada Dimensi Emphaty.

Analisis pada dimensi emphaty, dari sisi rata-rata dimensi menunjukkan bahwa secara umum kualitas pelayanan adalah masih kurang bagus, karena pelayanan yang diterima lebih rendah dari yang diharapkan konsumen. Skor yang ditunjukkan adalah -0,23.

2. Uji Hipotesis Kedua.

a. Hipotesis

H0 (hipotesis nol). Tidak ada perbedaan yang signifikan antara rata-rata kualitas pelayanan yang diharapkan konsumen dengan ratarata kualitas pelayanan yang dirasakan konsumen Radio JPI FM Solo.

$\mathrm{Ha}$ (Hipotesis alternatif)Ada perbedaan yang signifikan antara rata-rata kualitas pelayanan yang diharapkan konsumen dengan rata-rata kualitas pelayanan yang dirasakan konsumen Radio JPI FM Solo.

Dengan formulasi:

$\mathrm{H} 0 ; \mu \mathrm{es}=\mu \mathrm{ps}$

$\mathrm{Ha} ; \mu \mathrm{es} \neq \mu \mathrm{ep}$

b.Nilai Kritis

Pengujianyangdilakukan untukmenentukan apakahterjadi perbedaan ratarataantara kualitaspelayanan yangdiharapkan konsumen dan kualitas pelayanan yangdirasakankonsumenadalah pengujian dua sisi. Taraf nyata yang dipergunakanadalah 5\%, maka menurut tabel $\mathrm{Z}$, nilai $\mathrm{Z}$ adalah $\pm 1,96$.

c. Nilai Hitung

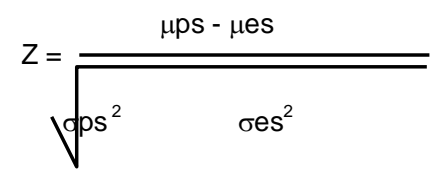




\section{$\overline{\text { Nps }}+\frac{}{\text { Nes }}$}

\begin{tabular}{|l|c|c|c|}
\hline & $\begin{array}{c}\text { Rata-rata Total } \\
(\mu)\end{array}$ & $\begin{array}{c}\text { Standar Deviasi } \\
(\sigma)\end{array}$ & $\begin{array}{c}\text { Jumlah } \\
\text { sampel }\end{array}$ \\
\hline $\begin{array}{l}\text { Harapan } \\
\text { Konsumen }\end{array}$ & 6,48 & 0,04 & 100 \\
\hline $\begin{array}{l}\text { Persepsi } \\
\text { Konsumen }\end{array}$ & 6,22 & 0,09 & 100 \\
\hline
\end{tabular}

Berdasarkan rumus diatas, maka dapat dihitung nilai Z:

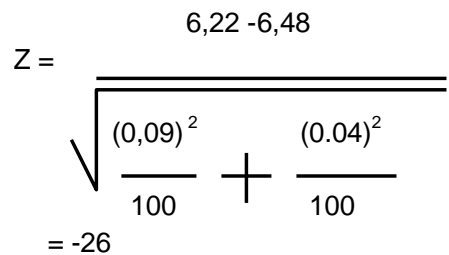

Taraf signifikan yang digunakan adalah $5 \%$, berarti nilai kritis $\mathrm{Z}=+-1,96$. Hasil ujistatistik pada penelitian ini adalah -26. Nilai ini terletak didaerah penolakan hipotesis nol, tepatnya berada disebelah kanan atau lebih kecil daripada -1,96 (lihatGambar V-1). Dengan demikian mengandung makna bahwa $\mathrm{H} 0$ ditolak. Kesimpulannya adalah ada perbedaan yang signifikan antara rata-rata kualitas pelayanan yang diharapkan konsumen dengan rata-rata kualitas pelayanan yang dirasakan konsumen.

\section{KESIMPULAN DAN SARAN}

\section{A. KESIMPULAN}

1. Kualitas Pelayanan Radio JPI FM Solo Secara Umum Berdasarkan Perbedaan Nilai Rata-rata Dimensi.

Berdasarkan penilaian skala yang ada, sebenarnya semua hasil dari nilai yang dirasakan bernilai tinggi. Meskipun demikian berdasarkan analisis data yang telah dilakukan, kualitas pelayanan Radio JPI FM pada umumnya masih kurang baik. Terlihat bahwa dari 5 dimensi kualitas pelayanan yang ada, tidak satupun bernilai positif. Kualitas pelayanan yang bernilai negatif ini menunjukkan bahwa pelayanan yang dirasakan konsumen lebih rendah daripada yang mereka harapkan.

2.Tingkat Kepuasan Konsumen terhadap Kualitas pelayanan Radio JPI FM Solo.

Tingkat kepuasan konsumen pada pelayanan Radio JPI FM Solodengan jelas pada skor servqual berdasarkan rerata item dan rata-rata dimensi (lampiran 4). Selisih skor servqual berdasarkan rerata dimensi pada pelayanan yang diharapkan dengan pelayanan yang dirasakan konsumen, yang memiliki tingkat tertinggi adalah pada dimensi assurance (-0.17). Jika diambil 4 tingkat kepuasan pertama, dilihat dari skor servqual berdasarkan rerata item, maka kepuasan tertinggi yang dirasakan konsumen adalah pada item ke-14 yang mempunyai nilai 0,29 yaitu mengenai sikap sopan santun yang dimiliki oleh karyawan Radio JPI FM dalam melayani konsumen. Tingkat kepuasan kedua ada pada item ke- 12 yang mempunyai nilai sebesar 0,09 yaitu mengenai kesediaan Radio JPI FM memberikan layanan khusus kepada konsumen. Tingkat kepuasan ketiga yang 
dirasakan

konsumen pada item ke-17 yang mempunyai nilai 0,05 yaitu Radio JPI FM memberikan perhatian individual kepada monitornya.

3. Komponen-komponen dalam Proses yang Harus segera Ditingkatkan Kinerjanya untuk Meningkatkan Kepuasan Konsumen secara Menyeluruh.

Dari analisa data yang telah dilakukan, terlihat bahwa dari sisi skor servqual erdasarkan rerata dimensi, diketahui bahwa Radio JPI FM harus meningkatkan kinerja pelayanannya pada setiap dimensi dari 5 dimensi yang ada. Komponen yang harus segera ditingkatkan kinerjanya untuk meningkatkan kepuasan konsumen dilihat dari sisi skor servqual berdasarkan rerata item dapat kita lihat pada 4 item terendah. Item terpenting yang harus mendapat perhatian adalah item ke-4 yang mempunyai skor terendah diantara 20 item yang ada. Item tersebut bernilai -0.63 yaitu item ke 10 mengenai karyawan yang selalu siap dan bersedia membantu konsumen. Komponen berikutnya adalah item ke-4 yang memiliki nilai -0,62 yaitu mengenai area parkir yang tersedia di Radio JPI FM. Komponen yang memiliki kinerja rendah berikutnya adalah item ke-20 yang mempunyai nilai sebesar -0,61 mengenai perhatian pada kebutuhan pribadi. Sedangkan komponen terakhir yang perlu mendapat perhatian adalah item ke-2 dan ke-15 yaitu mengenai citra profesional yang tercermin dari karyawan yang berpakaian rapi serta karyawan yang dapat dipercaya

\section{B. SARAN}

1. Pihak manajemen Radio JPI FM hendaknya dapat meningkatkan kualitas pelayanannya pada tiap dimensi, karena berdasarkan hasil penelitian inimonitor aktif beranggapan bahwa pelaksanan kelima dimensi tersebut belumdapat memuaskan monitor aktifnya

2. Mengingat monitor aktif menganggap seluruh atribut-atribut yang ada dalam penelitian ini cukup penting dan memiliki nilai pengaruh yang besar, maka adanya sikap cepat tanggap dari manajemen Radio JPI FM dalam menghadapi segala keluhan yang berkaitan dengan atribut-atribut tersebut utamanya atribut-atribut yang termasuk dalam lima dimensi yang ada.

3. Untuk mencapai kualitas pelayanan yang lebih baik dimasa yang akan datang, hendaknya manajemen Radio JPI FM melakukan survai kepuasan monitor aktifnya secara berkala untuk mengetahui kualitas pelayanan yang telah diberikan.

4. Perlu adanya interaksi dialog antara pihak manajemen Radio JPI FM maupun monitor aktifnya untuk dapat mengevaluasi sehingga akan ada usaha perbaikan kualitas pelayanan secara kontinyu.

\section{DAFTAR PUSTAKA}

Azwar, S (2000), Sikap Manusia Teori dan Pengukurannya, ed. 2. Yogyakarta: Pustaka Pelajar.

Budiyuwono, Nugroho (1993), Pengantar Statistik Ekonomi dan Perusahaan, Edisi Revisi, Yogyakarta:UPP AMP YKPN.

Cooper, Donald r. and Emory, C. William (1999), Metode Penelitian Bisnis, Jilid 2, Ed.5, Erlangga.

Cronin, J. Joseph and Taylor, Steven A (1994), "SERPERF Versus SERVQUAL: Reconciling Performance -Based and Perceptions - Minu s-Expectations 
Measurement of Service Quality," Journal of Marketing, Vol 58 (January),pp. 125131.

Dharmmesta, B.S. dan Handoko, Hani (2000), Manajemen Pemasaran: AnalisisPerilaku Konsumen, Yogyakarta:BPFE.

Dharmmesta, B.S. dan Irawan (2000), ManajemenPemasaran Modern, .2 Yogyakarta, Linerty.

Dharmmesta, B.S. (1994),"Perilaku Konsumen Indonesia Tahun 2000,” Kelola Gadjah Mada University Business Review, III,No.6, Mei, h.83-93.

Dutka, Alan F (1994), AMA Handbook for Customer Satisfaction: Research, Planning, and Implementation, Illionis USA: NTC Business Books in Association with The American Marketing Association.

James F. Engel, Roger D. Blackwell and Paul W. Miniard (1994), Perilaku Konsumen, Binarupa Aksara, Jakarta.

Kottler, Philip (2000), Marketing Management: Planninig, Implementation and Control, Millenium ed. Engelwoods Cliffs, New Jersey:Prentice-Hall Inc.

Lovelock, Christopher (1988), Managing Service: Marketing, Operation, and Human Resources, London: Prentice-Hall International Inc.

Nugroho Budiyuwono (1995), "Pengantar Statistik Ekonomi dan Perusahaan",Jilid 1,Edisi Revisi, UPP AMP YKPN, Yogyakarta.

Onong Uchjana Effendi (1983),Radio Siaran :Teori dan Praktek, Penerbit Alumni,Bandung.

Parasuraman, A.Valarie A. Zethaml and Leonard L. Berry (1985)," A ConceptualModel of Service Quality and Its Implications for Future Research, "Journal of Marketing, Vol.49 (Fall), pp.41-50.

Parasuraman. A, Valarie.A, Zeithaml and Leonard. L. Berry (1988), "Servqual: AMultiple Item Scale for Measuring Consumer Perceptions of Service Quality",Journal of Retailing, Vol.64, Number 1 (spring), pp.12-40.

Parasuraman, A.Valarie A. Zethaml and Leonard L. Berry (1994), "Reassesment of Expectation As a Comparison Standard in Measuring Service Implication for Future Research, "Journal ofMarketing, Vol.58 (January), pp. 111-124.

Radio JPI FM, (1995), Data Pola Siaran 1994-1995. -(2001), Data Pola Siaran 2001

Rhenald Kasali (1993), Manajemen Periklanan, Pustaka Utama Grafitti, Jakarta.

Suharsini Arikunto, DR, (1993), Prosedur Penelitian - Suatu Pendekatan Praktek, Edisi Revisi, Rineka cipta.

Singarimbun, Masri dan Effendy, Sofyan (Ed)(1989), Metode PenelitianSurvai, Edisi Revisi, Jakarta:LP3ES.

Stanton, William, J (1996), Prinsip Pemasaran,ed. 7, Jakarta:Penerbit Erlangga.

Tjipto, Fandy (2000), Manajemen Jasa, Yogyakarta: Penerbit Andi Offset.

Tjipto, Fandy (2000), Total Quality Service, Yogyakarta: Penerbit Andi Offset. Usahawan No. 07 Th XXX Juli 2001

Valerie A. Zeithaml and Mary Jo Bitner (1996), Service Marketing, McGraw HillBook Company. 